\title{
Magnetic Field Measurements by the Satellite Systems: A Review
}

\author{
Jyh-Woei Lin
}

\section{ABSTRACT}

Recently, in real-time the Disturbance storm time (Dst) indices observing by Geostationary Operational Environmental Satellite (GOES) was performable using so-called Goes-Magnetometer. Dst index is a geomagnetic index, which is the L1 data with the lead time, to detect geomagnetic storms with the lead time. Geomagnetic storms affected human activity and caused economic losses. Therefore, Dst index is a very important index. The past recorded contributions of corresponding Satellites were introduced. Now, in real-time Dst indices observing by Geostationary Operational Environmental Satellite (GOES-16) (GoesMagnetometer) was performed. However, the Dst index was not the issue in this study.

Keywords: Disturbance storm time (Dst) indices; Geostationary Operational Environmental Satellite (GOES); Goes-Magnetometer; Geomagnetic Storms; GOES-16.
Published Online: July 22, 2021

ISSN: 2684-446X

DOI : $10.24018 /$ ejgeo.2021.2.4.153

Jyh-Woei Lin*

Binjiang College, Nanjing University of Information Science \& Technology, Wuxi, 214105, Jiangsu Province, China, Department of Electrical Engineering, Southern Taiwan University of Science and Technology, Tainan, 710301, Taiwan.

(e-mail: pgjw11966@gmail.com)

*Corresponding Author

\section{INTRODUCTION}

In 1966, the first magnetic field measurement instruments were installed in geosynchronous orbit on the ATS-1 (Application Technology Satellite) (Table I), and operational measurements began with the SMS (Synchronous Meteorological Satellite) in May 1974 (Table II). Following two SMS satellites, the first Geostationary Operational Environmental Satellite (GOES) was launched in October 1975, which continued with two satellites called GOES-8 and GOES-9. These two satellites, instead of two SMS satellites, are used for space weather operations, e.g., recording magnetic field data. The GOES system's data are collected and processed by the National Oceanic and Atmospheric Administration (NOAA) Space Environment Center and are archived and distributed through the National Geophysical Data Center of NOAA. A continuous record spanning several decades is one of the advantages of these measurements over those made in other orbits over more limited time spans. In terms of describing the magnetometer instrument, the geosynchronous space environment, and the operational and scientific uses of the GOES magnetometer data, the magnetometers on the three-axis stabilized GOES I-M (1994-2013) (called GOES 8-12 after launch) series of satellites are three-axis fluxgate magnetometers manufactured by the Schonstedt Instrument Company, and they were integrated into the spacecraft by Space Systems [1]-[6]. In real-time Disturbance storm time (Dst) indices observing by Geostationary Operational Environmental Satellite (GOES-16) (Goes-Magnetometer) was performed (Fig. 1). Finally, the measurement of Dst index is not the issues in this study

\section{CORRESPONDING HowPAGES}

The information of the Application Technology Satellite (ATS) System as follows:

https://eospso.nasa.gov/missions/applications-technologysatellite.

The information of the Synchronous Meteorological Satellite (SMS) System as follows:

https://eospso.nasa.gov/missions/synchronousmeterological-satellite.

The information of the Geostationary Operational Environmental Satellite (GOES) System as follows:

https://www.nasa.gov/content/goes.

The information of The GOES I-M System (1994-2013) as follows:

https://eospso.nasa.gov/missions/geostationary-operationalenvironmental-satellites-i-m.

In real-time Dst indices observing by Geostationary Operational Environmental Satellite (GOES-16) (GoesMagnetometer) is as follows:

https://www.swpc.noaa.gov/products/goes-magnetometer.

\section{CONCLUSIONS}

Following SMS system, ATS-1 was used as first magnetic field instrument in 1966. The first Geostationary Operational Environmental Satellite (GOES) was used to recode magnetic field data in October 1975. These two satellites called GOES- 8 and GOES-9, instead of two SMS satellites, were used to record magnetic field data. Now, in real-time Dst indices observing by Geostationary Operational Environmental Satellite (GOES-16) (GoesMagnetometer) was performed. 
TABLE I: THE APPLICATION TECHNOLOGY SATELLITE (ATS) SYSTEM

\begin{tabular}{|c|c|c|c|c|}
\hline Mission & $\begin{array}{c}\text { Launch Date } \\
\text { (UTC) }\end{array}$ & Duration & Major investigations & Mission highlights \\
\hline ATS-1 & $\begin{array}{l}\text { December 7, } \\
\quad 1966\end{array}$ & 18 years & $\begin{array}{l}\text { Spin stabilization, investigated } \\
\text { the geostationary environment, } \\
\text { space communications }\end{array}$ & First full-Earth cloud cover images \\
\hline ATS-2 & April 6, 1967 & 6 months & $\mathrm{T}_{\mathrm{T}}$ & $\begin{array}{c}\text { Launch vehicle failure caused spacecraft } \\
\text { to reach undesirable orbit. Limited data } \\
\text { was obtained }\end{array}$ \\
\hline ATS-3 & $\begin{array}{c}\text { November } 5 \text {, } \\
1967\end{array}$ & $\begin{array}{l}\text { At least } 20 \\
\text { years }\end{array}$ & $\begin{array}{l}\text { Spin stabilization, } \\
\text { communications tests }\end{array}$ & $\begin{array}{l}\text { First color images from space. ATS-3 was } \\
\text { also used as a communications satellite, } \\
\text { providing links to Antarctica and the } \\
\text { Pacific Basin }\end{array}$ \\
\hline ATS-4 & $\begin{array}{l}\text { August 10, } \\
1968\end{array}$ & $\begin{array}{l}\text { launch } \\
\text { failure, } \\
\text { mission did } \\
\text { not occur }\end{array}$ & None & $\begin{array}{l}\text { Intended for geostationary orbit. Launch } \\
\text { vehicle failure left it in a useless LEO } \\
\text { orbit. Little data was obtained. }\end{array}$ \\
\hline ATS-5 & $\begin{array}{l}\text { August } 12 \text {, } \\
1969\end{array}$ & $\begin{array}{l}3 \text { year design } \\
\text { life }\end{array}$ & $\begin{array}{l}\text { Communications tests, intended } \\
\text { (failed) testing of an ion engine }\end{array}$ & $\begin{array}{l}\text { Spacecraft entered an unintended spin and } \\
\text { encountered excessive acceleration. This } \\
\text { caused damage to the ion engine. }\end{array}$ \\
\hline ATS-6 & May 30, 1974 & 5 years & $\begin{array}{c}\text { Tested several communications } \\
\text { technologies, satellite assisted } \\
\text { search and rescue, and broadcast } \\
\text { television. }\end{array}$ & $\begin{array}{l}\text { First satellite to broadcast educational } \\
\text { content. }\end{array}$ \\
\hline
\end{tabular}

TABLE II: THE SYNCHRONOUS METEOROLOGICAL SATELLITE (SMS) SYSTEM

\begin{tabular}{ccc}
\hline Designation & Launch Date (UTC) & Rocket \\
\hline SMS-1 & May 17, 1974 & Delta 2914 \\
SMS-2 & February 6, 1975 & Delta 2914 \\
\hline
\end{tabular}

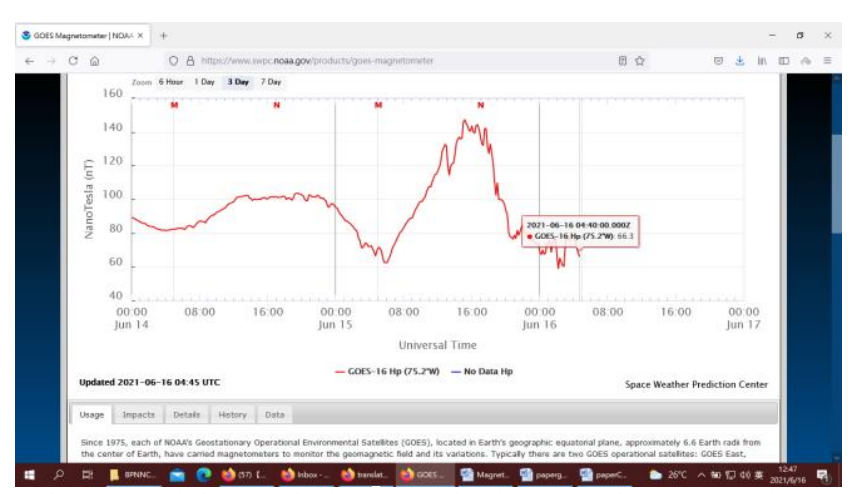

Fig. 1. In real-time Dst indices observing by Geostationary Operational Environmental Satellite (GOES-16).

\section{ACKNOWLEDGMENT}

The authors are grateful to National Oceanic and Atmospheric Administration (NOAA) for their information and Prof Dr. Yuan Mei (Taiwan) for the support. In realtime Dst indices observing by Geostationary Operational Environmental Satellite (GOES-16) (Goes-Magnetometer) is as follows:

https://www.swpc.noaa.gov/products/goes-magnetometer.

\section{REFERENCES}

[1] J. D. Barry and R. C, Snare, Fluxgate Magnetometer for the Applications Technology Satellite, IEEE Transactions on Nuclear Science, Vol. 13 (6), 326 - 332, doi: 10.1109/TNS.1996.4324379, 1966.

[2] D. N. Baker, R. D. Belian, P. R. Higbie and E. W. Hones-Jr, High-energy magnetospheric protons and their dependence on geomagnetic and interplanetary conditions, Journal of Geophysical
Research: Space Physics, Vol.84, A12, 7138-7154, doi: 10.1029/JA084iA12p07138, 1979.

[3] H. Singer, L. Matheson, R. Grubb, A. Newman and D. Bouwer, Monitoring space weather with the GOES magnetometers, Proceedings, Vol. 2812, GOES-8 and Beyond, 1996 Internal Symposium on Optical Science, Engineering, and Instrumentation, SPIE (the international society for optics and photonics), doi: 10.1117/12.254077, 1996

[4] P. Peitso, Space weather instruments and measurement platforms, Thesis, the degree of Master of Science in Technology, Department of Radio Science and Technology, School of Electrical Engineering, Aalto University, Finland, 2013.

[5] J. V. Rodriguez, J. C. Krosschell and J.C. Green, Intercalibration of GOES 8-15 solar proton detectors, Space Weather, Vol.12 (1), 92109, doi:10.1002/2013SW000996, 2014.

[6] J.W. Lin, Researching significant earthquakes in Taiwan using two back-propagation neural network models, Natural Hazards, Vol. 103, 3563-3590, doi: 10.1007/s11069-020-04144-z, 2020.

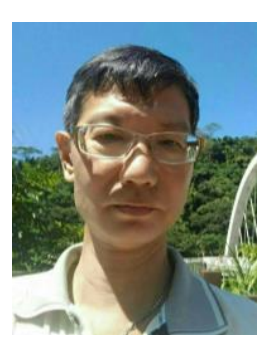

Jyh-Woei Lin (Stefan Lin) received the B. Sc. degree from the Department of Physics, Chung Yuan Christian University, Chung Li City, Taiwan, in 1989, the M.Sc. degree from the Institute of Geophysics, National Central University, Chung Li City, in 1991, the Ph.D. degree from the Institut für Geophysik, Clausthal-Zellerfeld, Technische Universit ät Clausthal, Germany, in 2000, and the Ph.D. degree from the Department of Electrical Engineering, Southern Taiwan University of Science and Technology, Tainan, Taiwan, in 2019. Since 2019, he is a researcher in the Department of Electrical Engineering, Southern Taiwan University of Science and Technology. Until 2021, he has about 70 SCI (SCIE) and EI papers include artificial intelligence, space physics, geophysics, medical sciences, and remote sensing; especially four books' publications in Germany and two books in USA. After September 2020, he is also as a Professor in Binjiang College, Nanjing University of Information Science \& Technology, Wuxi, Jiangsu Province, China. 